\title{
Transforming Hearts and Minds Concerning People with Disabilities: Viewing the UN Treaty Bodies and the Strasbourg Court through the Lens of Inclusive Equality
}

\author{
Andrea Broderick*
}

\begin{abstract}
The entry into force of the United Nations Convention on the Rights of Persons with Disabilities (CRPD) pushed state obligations to counter prejudice and stereotypes concerning people with disabilities to the forefront of international human rights law. The CRPD is underpinned by a model of inclusive equality, which views disability as a social construct that results from the interaction between persons with impairments and barriers, including attitudinal barriers, that hinder their participation in society. The recognition dimension of inclusive equality, together with the CRPD's provisions on awareness raising, mandates that states parties target prejudice and stereotypes about the capabilities and contributions of persons with disabilities to society. Certain human rights treaty bodies, including the Committee on the Rights of Persons with Disabilities and, to a much lesser extent, the Committee on the Elimination of Discrimination against Women, require states to eradicate harmful stereotypes and prejudice about people with disabilities in various forms of interpersonal relationships. This trend is also reflected, to a certain extent, in the jurisprudence of the European Court of Human Rights. This article assesses the extent to which the aforementioned human rights bodies have elaborated positive obligations requiring states to endeavour to change 'hearts and minds' about the inherent capabilities and contributions of people with disabilities. It analyses whether these bodies have struck the right balance in elaborating positive obligations to eliminate prejudice and stereotypes in interpersonal relationships. Furthermore, it highlights the convergences or divergences that are evident in the bodies' approaches to those obligations.
\end{abstract}

Keywords: CRPD, Disability Discrimination, ECHR, Stereotypes, Interpersonal Relations

\section{Introduction}

Ensuring effective protection against discrimination, including combating ingrained prejudice and stereotypes, is at the core of the quest to guarantee respect for

* Andrea Broderick is Assistant Professor at the Universiteit Maastricht, the Netherlands. human dignity. Adopting the lens of stereotyping enables one to look beyond 'intentional, negative behaviours' that underpin different forms of prejudice 'towards the (often) unintentional beliefs, assignment of certain roles and hierarchical orderings that structure our societies along different lines', according to Möschel. ${ }^{1}$

People with disabilities not only face countless disabling barriers in the built environment, but they also face disablist attitudes in both private and public life, hindering their ability to participate in mainstream society. Miller et al. define disablism as 'discriminatory, oppressive, or abusive behavior arising from the belief that disabled people are inferior to others' ${ }^{2}$ Discrimination against people with disabilities often results from ignorance and false assumptions and can manifest in 'aversive disablism' - subtle, unintentional prejudice - according to Deal. ${ }^{3}$

Prejudices and stereotyping often arise in the context of interpersonal relationships. These relationships can be classified as connections between private parties with varying degrees of proximity, arising, inter alia, in the family and social spheres, in the educational and employment spheres or in the field of healthcare.

International and regional human rights law has long paid attention to 'prejudice' and 'stereotypes'. The first reference to both of those terms in binding United Nations (UN) law is in Article 5(a) of the UN Convention on the Elimination of All Forms of Discrimination

1. M. Möschel, 'Racial Stereotypes and Human Rights', in E. Brems and A. Timmer (eds.), Stereotypes and Human Rights Law (2016) 119, at 120 For similar definitions of 'stereotypes' and 'prejudice', see J.F. Dovidio, M. Hewstone, P. Glick \& V.M. Esses, 'Prejudice, Stereotyping and Discrimination: Theoretical and Empirical Overview', in John F. Dovidio et al. (eds.), The SAGE Handbook of Prejudice, Stereotyping and Discrimination (2010) 3, at 5-9.

2. P. Miller, S. Parker \& S. Gillinson, Disablism: How to Tackle the Last Prejudice (2004), at 9; see also F. Campbell, Frontiers of Ablism (2009); and P. Harpur, 'Sexism and Racism, Why Not Ablism?: Calling for a Cultural Shift in the Approach to Disability Discrimination', 35(3) Alternative Law Journal 163 (2009). 'Ablism' is a preferred term by certain researchers, as it focuses not only on disability but the formation of abledness, which is always in relationship with disability: www.coe.int/en/web/compass/disability-and-disablism\#19 (last visited 1 April 2020).

3. M. Deal, 'Aversive Disablism: Subtle Prejudice Toward Disabled People', 22(1) Disability \& Society 93, at 93 (2007). 
against Women (CEDAW). ${ }^{4}$ In addition, Article 7 of the International Convention on the Elimination of All Forms of Racial Discrimination (CERD) ${ }^{5}$ requires that states parties combat prejudice.

It was not until the entry into force of the UN Convention on the Rights of Persons with Disabilities (CRPD) ${ }^{6}$ and the mandate of the Committee on the Rights of Persons with Disabilities (CRPD Committee), that state obligations to counter prejudice and stereotypes against people with disabilities were pushed to the forefront of international human rights law, becoming 'a growing area of interest within the UN' ${ }^{7}$ Other UN bodies, such as the Committee on the Elimination of All Forms of Discrimination against Women (CEDAW Committee), have acknowledged the existence of compounded disability stereotyping. ${ }^{8}$ Moreover, regional bodies, such as the European Court of Human Rights (ECtHR), have increasingly taken note of disability as a human rights issue.

While much has been written about prejudice and stereotypes in the disability context, ${ }^{9}$ and some attention has been paid in the legal literature to the issue of disability prejudice and stereotypes in interpersonal relationships,${ }^{10}$ these issues have not yet been analysed from the perspective of the jurisprudence of the UN treaty bodies and the ECtHR in the context of the CRPD's model of inclusive equality. That model of equality views disability as a social construct that results from the interaction between persons with impairments and barriers, including attitudinal barriers, that hinder their participation in society.

Against the backdrop of the CRPD's model of inclusive equality, this article assesses the extent to which the aforementioned bodies have elaborated positive obligations to protect and fulfil disability rights, requiring states to endeavour to change 'hearts and minds' ${ }^{\prime 1}$ about

4. Convention on the Elimination of All Forms of Discrimination against Women, adopted and opened for signature, ratification and accession by General Assembly resolution 34/180 of 18 December 1979.

5. International Convention on the Elimination of All Forms of Racial Discrimination, adopted and opened for signature and ratification by General Assembly resolution 2106 (XX) of 21 December 1965.

6. UN Convention on the Rights of Persons with Disabilities, 13 December 2006, UN Doc. A/RES/61/106, Annex I.

7. S. Cusack, 'Building Momentum Towards Change: How the UN's Response to Stereotyping is Evolving', in E. Brems and A. Timmer, above n. 1, at 19.

8. See, for instance, Committee on the Elimination of All Forms of Discrimination Against Women (CEDAW Committee), General Recommendation 25, UN Doc. A/59/38, Annex I (2004), para. 12.

9. See, for instance, P. Hunt, Stigma: The Experience of Disability (1996). See also M.L. Perlin, The Hidden Prejudice: Mental Disability on Trial (2000). See also J. Morris, Pride Against Prejudice: Transforming Attitudes to Disability: A Personal Politics of Disability (1991); and C. Friedman, 'The Relationship between Disability Prejudice and Disability Employment Rates', 65(3) Work 591 (2020).

10. See, among others, R.J. Bonnie and J. Monahan (eds.), Mental Disorder, Work Disability, and the Law (1997); See also P.D. Blanck (ed.), Employment, Disability and the Americans with Disabilities Act: Issues in Law, Public Policy and Research (2000).

11. See Chief Justice Warren's opinion in Brown v. Board of Education of Topeka. See also M. Perlin, 'My Sense of Humanity Has Gone Down the Drain: Stereotypes, Stigma and Sanism', in E. Brems and A. Timmer, above n. 1, at 104 the inherent capabilities and contributions to society of people with disabilities. It analyses whether the relevant bodies have struck the right balance or overstepped the mark and whether any fragmentation ${ }^{12}$ or convergence ${ }^{13}$ is evident in their respective approaches. In terms of its scope, this article primarily addresses jurisprudence which relates to prejudice and stereotypes that occur in relations between private parties, but it also discusses disablism, which - directly or indirectly - affects the exercise of the rights of people with disabilities in the aforementioned interpersonal spheres.

This article is rooted in legal doctrinal methodology. ${ }^{14}$ In that regard, it is 'descriptive, evaluative and critical' 15 of the most relevant legal sources. The selection of jurisprudence was made by inputting the terms 'stereo*', 'prejudice' and 'disability' in the databases of the Office of the High Commissioner for Human Rights, the Universal Human Rights Index and Human Rights Documentation (HUDOC). ${ }^{16}$ In addition, the article takes account of other jurisprudence related to disability discrimination and associated legal literature.

Following the introductory remarks, Section 2 of this article discusses horizontal positive obligations in international and regional law. Section 3 addresses the CRPD's theoretical framework - that of inclusive equality - and its distinctive features related to prejudice and stereotyping. That section also analyses the extent to which the issues of prejudice and stereotyping related to disability have been mainstreamed in other UN treaty bodies. Section 4 then examines the relevant case law decided under the European Convention on Human Rights (ECHR), ${ }^{17}$ while Section 5 highlights the fragmentation or convergence that is evident in the respective approaches of the bodies examined. Finally, Section 6 contains concluding remarks.

\section{Horizontal Positive Obligations in International and Regional Law}

Since much of this article analyses jurisprudence which relates to prejudice and stereotypes that occur in relations between private parties, this section sets out the

12. See UN General Assembly, Fragmentation of International Law: Difficulties Arising from the Diversification and Expansion of International Law. Report of the Study Group of the International Law Commission, UN Doc. A/CN.4/L.682 (2016), at 245.

13. See generally M. Andenas and E. Bjorge (eds.), A Farewell to Fragmentation: Reassertion and Convergence in International Law (2015).

14. H.T. Emerson and F.B. Cross, 'What is Legal Doctrine', 100(1) Northwestern University Law Review 517, at 518 (2005).

15. A. Broderick, The Long and Winding Road to Equality and Inclusion for Persons with Disabilities: The United Nations Convention on the Rights of Persons with Disabilities (2015), at 14.

16. Searches were updated to 26 February 2020.

17. Convention for the Protection of Human Rights and Fundamental Freedoms, Rome, 4.XI.1950. 
horizontal positive obligations that are incumbent on states under international and regional law.

\subsection{Regulating Discrimination in the Private} Sphere in International Human Rights Law As highlighted elsewhere,

[w]hile enforcement mechanisms for international human rights law ${ }^{18}$ address themselves solely to States, the doctrine of horizontal application of human rights law has developed, ${ }^{19}$

acknowledging state party responsibility for discrimination perpetrated by non-state actors. Nowak contends that

the primary significance of protection against discrimination lies in the obligation on States Parties to provide effective protection against discrimination by private parties to those subject to their laws. ${ }^{20}$

Article 4(1)(e) CRPD is modelled closely on Article 2(e) CEDAW ${ }^{21}$ in that it requires states parties to the CRPD to 'take all appropriate measures to eliminate discrimination on the basis of disability by any person, organization or private enterprise'. The CRPD also contains explicit references to action to be taken by private actors in Articles 9(2)(b), on accessibility; 21(c), on freedom of information and expression; 25(d), on health and 27(1)(h), on employment.

It is evident that the foregoing treaties prohibit discriminatory conduct in market-based private relationships, such as in access to employment or goods and services. Notwithstanding this, one cannot automatically assume that this extension of state responsibility to private actors also applies to interactions in the sphere of intimacy - pertaining (among others) to private, social and family life.

Henrard submits that the CERD does not impose positive obligations 'to prevent and eradicate private discrimination in a comprehensive way that would reach every interaction between private persons'. ${ }^{22}$ This contention needs to be considered in light of the CRPD, which has taken a step further into the sphere of intimacy than previous international human rights law. In that regard, Article 23 CRPD (on respect for the home and family) requires states parties to 'take effective and appropriate measures to eliminate discrimination against persons with disabilities in all matters relating to marriage, family, parenthood and relationships' ${ }^{23}$

18. With the exception of international criminal law

19. See generally P. Alston, Non-State Actors and Human Rights (2004).

20. M. Nowak, UN Covenant on Civil and Political Rights: CCPR Commentary (2005), at 632

21. See also Art. 2(1)(d) CERD.

22. K. Henrard, 'Non Discrimination and Full and Effective Equality', in M. Weller (ed.), Universal Minority Rights: A Commentary on the Jurisprudence of International Courts and Treaty Bodies (2007), at 143.

23. See also Committee on the Rights of Persons with Disabilities (CRPD Committee), Bacher v. Austria, UN Doc. CRPD/C/19/D/26/2014, para. 9.2.
2.2 The Troubled Relationship of the Strasbourg Court with Horizontal State Responsibility

The drafters of the ECHR did not intend the Convention to extend to relationships between private individuals. ${ }^{24}$ Notwithstanding this, the Strasbourg Court has affirmed the existence of horizontal positive obligations,${ }^{25}$ with a view to giving 'practical' effect to certain provisions of the Convention. ${ }^{26}$ By means of the wellestablished margin of appreciation doctrine, however, the Court leaves wide discretion to national authorities with regard to positive duties. It is 'conscious of the limits of its mandate and endeavours to respect national resource allocation policies'. ${ }^{27}$ As de Schutter points out, the difficulty in interpreting the socio-economic dimensions of ECHR rights lies in identifying 'the precise scope of the positive obligations which may be imposed on the State'. ${ }^{28}$ In particular, when positive obligations are substantive (rather than procedural) in nature, there is a particular need to balance colliding rights and freedoms and to respect the restrictions or limitations applying to ECHR rights. ${ }^{29}$

It is indisputable that the ECHR diverges significantly from UN treaties, and particularly from the CRPD, in terms of the ratione materiae of the rights and obligations contained therein. While the CRPD is a groupspecific treaty that 'contains widespread positive duties [spanning] both civil and political as well as economic, social and cultural rights', the 'fundamental aim of the ECHR is to protect civil and political rights'. ${ }^{30}$ Moreover, the ECHR places 'primarily negative restraints on governmental action and does not contain any specific provisions for the protection of the rights of persons with disabilities', ${ }^{31}$ although it has been interpreted as covering disability. ${ }^{32}$

24. See generally L. Urbaite, 'Judicial Activism in the Approach of the European Court of Human Rights to Positive Obligations of the State', 11 Baltic Yearbook of International Law 214 (2011).

25. See generally A. Mowbray, The Development of Positive Obligations under the European Convention on Human Rights by the European Court of Human Rights (2004)

26. M. Florczak-Wator, 'The Role of the European Court of Human Rights in Promoting Horizontal Positive Obligations of the State', 17(2) International and Comparative Law Review 39, at 40 (2017). See generally L. Lavrysen, Human Rights in a Positive State: Rethinking the Relationship between Positive and Negative Obligations under the European Convention on Human Rights (2016), at 50-53.

27. A. Broderick, 'The Convention on the Rights of Persons with Disabilities and the European Convention on Human Rights: A Tale of Two Halves or a Potentially Unified Vision of Human Rights?', 7(2) Cambridge International Law Journal 199, at 206 (2018). See generally D. Xenos, The Positive Obligations of the State under the European Convention on Human Rights (2012).

28. O. de Schutter, 'Reasonable Acommodation and Positive Obligations in the European Convention on Human Rights', in A. Lawson and C. Gooding (eds.), Disability Rights in Europe: From Theory to Practice (2005), at 45

29. See generally J. Gerards, General Principles of the European Convention on Human Rights (2019).

30. With the exception of the First Protocol to the ECHR (concerning the right to property and the right to education). Broderick (2018), above $n$. 27, at 202.

31. Broderick (2018), above n. 27, at 202-3. See Art. 5(1)(e) ECHR, concerning the lawful detention of 'persons of unsound mind'.

32. Glor v. Switzerland, ECHR (2009), Application no. 13444/04 
In recent years, the Strasbourg Court has elaborated a 'burgeoning disability jurisprudence on the non-discrimination norm'. ${ }^{33}$ However, in the sphere of relationships between private parties, the Court wavers in terms of imposing positive obligations on states. Furthermore, the ECtHR has recognised that state obligations are not absolute, particularly concerning the extent to which human rights are to be respected in relations between private parties. In that regard, the Court often resorts to the 'fair balance' test. ${ }^{34}$ In other words, in determining whether a positive obligation exists, the Court holds that a fair balance must be struck between the interests of the community on the whole and the interests of the individual. ${ }^{35}$

Overall, one must question how far the international and regional treaty-monitoring bodies are prepared to reach into the sphere of interpersonal relations, both in instances involving prejudice and stereotypes perpetrated by private actors and those perpetrated by professionals (such as psychiatrists) or individuals linked to the state (such as judges) that affect the interpersonal relations of people with disabilities. Furthermore, the question remains as to what types of measures can be effective in changing hearts and minds towards people with disabilities and in ensuring inclusive equality. The following sections reflect on these questions.

\section{The UN Treaty Bodies: Addressing Prejudice and Stereotypes}

3.1 The UN CRPD: A Treaty of Paradigm Shifts The adoption of the CRPD on 13 December 2006, and its entry into force on 3 May 2008, represents the 'highwater mark ${ }^{36}$ concerning the protection of the rights of persons with disabilities in international human rights law. O'Cinneide argues that the CRPD adopts 'a particular conceptual view' of the state's role, whereby states parties bear various positive obligations spanning all human rights, designed to ensure the provision of a minimum level of support to persons with disabilities that is compatible with their inherent dignity. ${ }^{37}$ Stein notes that the CRPD challenges the traditional gap between civil and political rights, and socio-economic

33. D. Ferri and A. Broderick, 'The European Court of Human Rights and the "Human Rights Model of Disability": Convergence, Fragmentation and Future Perspectives', European Yearbook on Human Rights (2019), at 276.

34. Gerards, above n. 29, at 154 et seq.

35. See, among many others, Hatton v. United Kingdom, ECHR (2003), Application no. 36022/97.

36. A. Broderick and D. Ferri, International and European Disability Law and Policy: Text, Cases and Materials (2019), at 311.

37. C. O'Cinneide, 'Extracting Protection for the Rights of Persons with Disabilities from Human Rights Frameworks: Established Limits and New Possibilities', in O.M. Arnardóttir and G. Quinn (eds.), The UN Convention on the Rights of Persons with Disabilities: European and Scandinavian Perspectives (2009), at 164 rights. ${ }^{38}$ Moreover, scholars claim that by blurring the distinction between these traditional categories of rights, the CRPD has resulted in increasing the range of positive obligations that reach into both the public and private spheres. ${ }^{39}$ In that connection, de Beco confirms that the CRPD 'has generated a new understanding of the indivisibility of human rights'. ${ }^{40}$

\subsubsection{The Theoretical Framemork of the UN CRPD}

The CRPD endorses the paradigm shift from the outdated medical model of disability - which perceives of the inability of people with disabilities to participate in society as the inevitable result of their own impairment rather than as a consequence of any disabling and discriminatory barriers in society' ${ }^{41}$ - to the 'social-contextual model' of disability. ${ }^{42}$ The CRPD's version of the social model ${ }^{43}$ views disability as an interaction between persons with impairments and widespread barriers in society (physical barriers, as well as legal and attitudinal barriers, among others) and has been described as 'a bulwark against disablism'. ${ }^{44}$ The primary focus of the CRPD is on the elimination of barriers through positive measures such as individualised reasonable accommodations ${ }^{45}$ - modifications that are needed or requested by a particular individual in a specific case, such as extra time in an examination or the adjustment of working facilities - and generalised (group-based) anticipatory accessibility measures. ${ }^{46}$

Article 2 CRPD sets out a wide definition of discrimination on the basis of disability, highlighting that such discrimination includes the denial of a reasonable accommodation. The accommodation duty is subject to a defence or limitation, whereby the duty bearer is not required to provide an accommodation where to do so would impose a disproportionate or an undue burden.

Degener suggests that while a social model approach to disability explains how disability arises and sheds light on the marginalisation of people with disabilities, it does not offer adequate solutions to overcome it. ${ }^{47}$ The substantive provisions of the CRPD go beyond the socialcontextual model, to endorse the human rights model of

38. M.A. Stein, 'Disability Human Rights', 95 California Law Review 75, at 75 (2007).

39. Broderick (2018), above n. 27, at 207

40. G. de Beco, 'The Indivisibility of Human Rights in Light of the Convention on the Rights of Persons with Disabilities', 68(1) International and Comparative Law Quarterly 141, at 160 (2019).

41. Broderick (2015), above n. 15, at 1

42. Ibid., at 77

43. Several authors claim that the 'pure' social model focuses on societal barriers and neglects the role of impairment in disabling individuals: see T. Shakespeare and N. Watson, 'The Social Model of Disability: An Outdated Ideology?', 2 Research in Social Science and Disability 9 (2001).

44. A. Dimopolous, 'An Enabling Interpretation of the Refugee Convention: Determination of Refugee Status in Light of the Convention on the Rights of Persons with Disabilities', in B. Burson and David J. Cantor (eds.), Human Rights and the Refugee Definition: Comparative Legal Practice and Theory (2016) 253, at 258

45. See Arts. 2 and 5(3) CRPD.

46. See Art. 9 CRPD.

47. T. Degener, 'A New Human Rights Model of Disability', in V. Della Fina, R. Cera \& G. Palmisano, (eds.), The United Nations Convention on the Rights of Persons with Disabilities: A Commentary (2017) 41, at 41 
disability. ${ }^{48}$ The latter model lays emphasis on the human dignity of persons with disabilities and values impairments as part of human diversity. ${ }^{49}$ The human rights model also conceives of disability as 'one of several layers of identity', requiring states parties to address intersectional disadvantage. ${ }^{50}$ Quinn and Degener clarify that the end goal of the human rights model is to build societies that are genuinely inclusive, societies that value difference and respect the dignity and equality of all human beings regardless of difference'. ${ }^{51}$

\subsubsection{Peering through the Lens of Inclusive Equality: Recognising Inherent Abilities}

The human rights model is mirrored in the CRPD's mandate of inclusive equality, ${ }^{52}$ which has been defined by the CRPD Committee as a 'new' model of equality developed through the CRPD's provisions. ${ }^{53}$ According to the Committee, the inclusive equality model goes beyond a substantive model of equality, by embracing four intertwined dimensions:

i. An accommodating dimension: to make space for difference as a matter of human dignity

ii. A fair redistributive dimension: to address socioeconomic disadvantage

iii. A participative dimension: to reaffirm the social nature of people as members of social groups and the full recognition of humanity through inclusion in society

iv. A recognition dimension: to combat stigma, stereotyping, prejudice and violence and to adequately take into account the dignity of human beings and their intersectionality. ${ }^{54}$

The recognition dimension of inclusive equality is reflected in the transversal provision on awareness raising in Article 8 CRPD, termed an obligation of 'social engineering'. 55 Article 8 CRPD requires that states parties adopt immediate, ${ }^{56}$ effective and appropriate measures to raise awareness, including at the family level, regarding persons with disabilities. ${ }^{57}$ It also requires states parties to combat stereotypes, prejudices and harmful practices related to persons with disabilities, including those based on sex and age, in all areas of life. ${ }^{58}$ Measures envisaged by the CRPD to foster

48. CRPD Committee, General Comment 6, UN Doc. CRPD/C/GC/6 (2018), para. 9. See also Broderick (2015), above n. 15, at 26-28.

49. Degener, above n. 47 , at 47 .

50. CRPD Committee, above n. 48, para. 9.

51. G. Quinn and T. Degener, Human Rights and Disability, Human Rights and Disability (2002), at 14. See also General Principle 3(d) CRPD.

52. CRPD Committee, above n. 48, para. 11

53. Ibid. In connection with the CRPD Committee's model of inclusive equality, see the parallels with the analysis of equality in Broderick (2015), above n. 15, and with Sandra Fredman's four-dimensional model of transformative equality: S. Fredman, Discrimination Law (2011).

54. CRPD Committee, above n. 48, para. 11.

55. C. Tobler, The Limits and Potential of the Concept of Indirect Discrimination (2008).

56. Interestingly, Art. 8 is the only CRPD provision to require the adoption of 'immediate' measures.

57. Art. 8(1)(a) CRPD

58. Art. 8(1)(b) CRPD. respect for the rights of people with disabilities include promoting recognition of their skills, merits and abilities and their contribution to the workplace ${ }^{59}$ fostering an attitude of respect at all levels of the education system, including in all children from an early age, ${ }^{60}$ encouraging all organs of the media to portray persons with disabilities in a manner consistent with the CRPD ${ }^{61}$ and promoting training programmes. ${ }^{62}$

Education is an important tool in countering intolerance and fostering understanding. In that connection, Article 8(2)(b) CRPD echoes the requirement under Article 24 CRPD to ensure an inclusive educational system, which is targeted, inter alia, towards the 'the full development of human potential and sense of dignity and self-worth, and the strengthening of respect for human rights, fundamental freedoms and human diversity'. ${ }^{63}$ By ensuring inclusion of individuals with various types of impairments in educational systems, disability becomes part and parcel of human diversity, and that, in turn, can be reflected in educational curricula.

Article 8 CRPD is also closely intertwined with the nondiscrimination norm (in Arts. 2 and 5 CRPD), which has been described as the 'leitmotif' of the CRPD. ${ }^{64}$ The non-discrimination principle cuts across both civil and political rights, and economic, social and cultural rights, as do its corresponding obligations. Moreover, the CRPD prohibits multiple and intersectional discrimination, in Article 6 thereof.

Overall, the CRPD embraces a model of equality which seeks to target deep-rooted structural inequalities by advocating legal tools, including individualised support measures for people with disabilities, to enable them to live independently in their communities, ${ }^{65}$ to participate in mainstream education ${ }^{66}$ and on the open labour market $^{67}$ - thereby normalising disability in everyday life and targeting all forms of disablism.

Another recognition duty is found in Article 12 CRPD, which accords individuals with disabilities equal recognition before the law (legal capacity), meaning that they have the right to legal standing and legal agency. ${ }^{68}$ Perceived or actual deficits in mental capacity ('unsoundness of mind' or other discriminatory labels) cannot be employed to justify a denial of legal capacity, according to the CRPD Committee. ${ }^{69}$ Article 12 CRPD envisages the shift from the substitute decision-making paradigm (guardianship or other) to one that is based on supported decision-making. ${ }^{70}$ This means that all forms of

59. Art. 8(2)(a)(iii) CRPD

60. Art. 8(2)(b) CRPD.

61. Art. 8(2)(c) CRPD.

62. Art. 8(2)(d) CRPD.

63. Art. 24(1)(a) CRPD

64. O.M. Arnardóttir, 'A Future of Multidimensional Disadvantage Equality', in O.M. Arnardóttir and G. Quinn, above n. 37, at 41.

65. Art. 19 CRPD.

66. Art. 24 CRPD.

67. Art. 27 CRPD.

68. CRPD Committee, General Comment 1, UN Doc. CRPD/C/GC/1 (2014), para. 12

69. Ibid., para. 13.

70. Ibid. On the 'best interests standard' and its compatibility with the CRPD, see generally P. Gooding, A New Era for Mental Health Law and 
guardianship are outlawed under the CRPD, and the best interests standard - which is inherently paternalistic $^{71}$ and based on prejudice and stereotypes that people with disabilities are incapable - can no longer be used as a justification for depriving them of their decision-making abilities. In fact, the CRPD Committee is of the view that all individuals, no matter how severe their impairment, have 'universal legal capacity'. ${ }^{72}$ Moreover, Article 12(3) CRPD requires states parties to provide persons with disabilities with the necessary supports to make decisions and exercise their legal capacity in accordance with their will and preferences. ${ }^{73}$ ArsteinKerslake and Flynn note that

an individual's 'will' is used to describe the person's long-term vision of what constitutes a 'good life' for them. ${ }^{74}$ The term 'preferences', on the other hand, tends to refer to likes and dislikes, or ways in which a person prioritises different options available to them. ${ }^{75}$

Notably, the CRPD Committee's interpretation of certain provisions, particularly that on legal capacity, has not been without controversy. ${ }^{76}$ The Committee's interpretation of the right to legal capacity has been considered contentious by some scholars, who argue that it seems to go 'further than recommending governments end guardianship' and 'calls on countries to abolish mental health laws' ${ }^{77}$ Other scholars seem to imply that support may not be a feasible option for certain individuals with disabilities. ${ }^{78}$

\subsubsection{The CRPD Committee: Hitting the Right Target or Aiming Wide of the Mark in Ruling on Prejudice and Stereotypes?}

This subsection examines the decisions, concluding observations and general comments of the CRPD Committee that pertain to prejudice and stereotyping in interpersonal relationships, with a view to delineating the trends that are evident in the Committee's jurisprudence from the perspective of positive duties.

Policy: Supported Decision-Making and the UN Convention on the Rights of Persons with Disabilities (2017), at 129 et seq.

71. M. Donnelly, 'Decision Making for Mentally Incompetent People: The Empty Formula of Best Interests?', 20 Medical Law Journal 405 (2001).

72. CRPD Committee, above n. 68, para. 25.

73. Ibid., para. 17.

74. A. Arstein-Kerslake and E. Flynn, 'The General Comment on Article 12 of the Convention on the Rights of Persons with Disabilities: A Roadmap For Equality Before the Law', 20(4) The International Journal of Human Rights 471, at 471 (2016). CRPD Committee, above n. 68, para. 21. See also Art. 12(4) CRPD

75. Arstein-Kerslake and Flynn, above n. 74, at 471.

76. See the comments at www.ohchr.org/en/hrbodies/crpd/pages/ dgcarticles12and9.aspx (last visited 1 April 2020).

77. See J. Craigie, M. Bach, S. Gurbai, A. Kanter, S.Y.H. Kim, O. Lewis \& G. Morgan, 'Legal Capacity, Mental Capacity and Supported DecisionMaking: Report from a Panel Event', 62 International Journal of Law and Psychiatry 160, at 160 (2019).

78. M. Browning, C. Bigby \& J. Douglas, 'Supported Decision Making: Understanding How Its Conceptual Link to Legal Capacity Is Influencing the Development of Practice', 1(1) Research and Practice in Intellectual and Developmental Disabilities 34 (2014).
Using the search terms indicated in Section 1, three relevant individual communications were identified.

One example of a decision in which the CRPD Committee reached into the interpersonal sphere is $X \mathrm{v}$. Tanzania, decided in 2017. ${ }^{79}$ The author of that individual communication, Mr. X, had his left arm cut off by two strangers at the age of 41 due to his condition of albinism.

The CRPD Committee considered that the domestic authorities had not acted with due diligence, having failed to take the necessary measures to ensure 'an effective, complete and impartial investigation and prosecution of the perpetrators' ${ }^{80}$ Accordingly, the Committee found that the state party had violated Articles 5 (on non-discrimination); 15 (on freedom from torture, cruel, inhuman and degrading treatment) and 17 CRPD (on respect for integrity). ${ }^{81}$

A parallel finding of discrimination was made by the CRPD Committee a year later in $Y$ v. Tanzania, ${ }^{82}$ in circumstances that were largely similar to those in the decision of $X$.

The authors of both communications alleged disabilitybased discrimination because i) the violence in question was a generalised practice in the state party that only affects people with albinism and ii) the impunity connected to the acts

characterises most cases of violence perpetrated against persons with albinism, as the State party's authorities considered that such violence is linked to witchcraft, which is a generally accepted cultural practice with regard to which a lot of prejudice still prevails in society. ${ }^{83}$

In both decisions, the CRPD Committee prescribed both training and awareness-raising measures designed to address 'harmful practices and rampant myths' affecting the rights of individuals with albinism, ${ }^{84}$ and also called for the criminalisation of such practices ${ }^{85}$ and the adaptation of legal frameworks 'to ensure that they encompass all aspects of attacks against persons with albinism'. ${ }^{86}$ This reflects, perhaps, the Committee's awareness of the limitations of educational measures alone and the view that some coercive measures are necessary in this context.

Endeavouring to change hearts and minds by invoking the tool of criminal law is a solution that is open to question. ${ }^{87}$ Not only is persistent harassment at the interpersonal level difficult to police, necessitating

CRPD Committee, X v. Tanzania, Communication No. 22/2014, UN Doc. CRPD/C/18/D/22/2014 (2017).

80. Ibid., para. 8.2

81. Ibid., para. 8.6

82. CRPD Committee, Y v. Tanzania, Communication No. 23/2014, UN Doc. CRPD/C/18/D/23/2014 (2018).

83. See paras. 8.2 of $X$ v. Tanzania and $Y$ v. Tanzania.

84. See paras. 9(b)(iv) of $X$ v. Tanzania and $Y$ v. Tanzania.

85. See paras. $9(\mathrm{~b})$ (iii) of $X \mathrm{v}$. Tanzania and $Y$ v. Tanzania.

86. See paras. $9(\mathrm{~b})(\mathrm{i})$ of $X$ v. Tanzania and $Y$ v. Tanzania. Emphasis added.

87. See, among others, L. Piggott, 'Prosecuting Disability Hate Crime: A Disabling Solution', 5(1) People, Place \& Policy Online 25 (2011). 
coordinated action at various levels of government, but institutional prejudices that are already embedded in a given culture are extremely difficult to overcome. In that regard, law can serve to pull hearts and minds in one direction, but embedded cultural traditions or religion can influence one's affective and cognitive faculties to such an extent that they essentially pull hearts and minds in the opposite direction. Moreover, criminalisation can suppress minds to the reality of the experience of disability (albinism in this case), rather than opening minds to becoming more tolerant. In addition, legislation targeting hate crime underlines the problem 'as caused by the individual who goes out in public', ${ }^{88}$ thereby reinforcing culturally embedded ideas of normality and disability. ${ }^{89}$ This can lead to institutionalised stigmatisation and 'othering' and may also entrench aversive disablism. Furthermore, prescribing a criminal law remedy ignores the manifold barriers that people with disabilities face in the criminal justice system generally, ${ }^{90}$ and especially in one that is probably also steeped in cultural prejudices.

Another area in which people with disabilities are greatly stigmatised concerns the exercise of their legal capacity. Legal capacity considerations relate closely to the interpersonal sphere, since many important decisions taken by, or in respect of, people with disabilities are adopted in that sphere. In 2013, the CRPD Committee handed down an individual communication on legal capacity, in which it deliberated indirectly on prejudices stemming from private individuals (professionals) deciding on the issue of guardianship. While the substance of the case of Bujdosó and others ${ }^{91}$ did not relate to the interpersonal sphere itself - concerning instead the placement of individuals with intellectual disabilities under partial or plenary guardianship regimes pursuant to various judicial decisions, and the ensuing denial of their right to vote - certain aspects of the case are nonetheless noteworthy in the context of prejudice and stereotyping, and those aspects will be elaborated on in a later section of this article. ${ }^{92}$

The third-party interveners in Bujdosó emphasised that restricting the right to vote on the basis of disability constitutes direct discrimination and is 'predicated on the unacceptable and empirically unfounded stereotype that all persons with disabilities are incapable'. ${ }^{93}$ In rendering its decision, the CRPD Committee took note of the interveners' claims that 'the professionals who participate in the assessment process, such as judges, psychologists, psychiatrists and social workers, are not immune to such prejudice'. ${ }^{94}$ Taking into account these arguments, the Committee made clear that no individual

88. Ibid., at 28-29.

89. Ibid., at 25

90. See generally E. Flynn, Disabled Justice?: Access to Justice and the UN Convention on the Rights of Persons with Disabilities (2017).

91. CRPD Committee, Zsolt Bujdosó and Others v. Hungary, Communication No. 4/2011, UN Doc. CRPD/C/10/D/4/2011 (2013).

92. See Subsection 4.4

93. CRPD Committee, Zsolt Bujdosó and Others v. Hungary, above n. 91, para. 5.4 .

94. Ibid., para. 5.11 . with a disability should be forced to undergo an assessment of voting capacity by social workers, psychologists or others as a precondition for participating in elections and that states parties should put in place all requisite positive measures of support. ${ }^{95}$

In terms of the CRPD Committee's concluding observations, ${ }^{96}$ Cusack notes that, between 2011 and 2014, there were a 'small but growing number' of concluding observations issued by the Committee in relation to prejudice and stereotypes. ${ }^{97} \mathrm{Up}$ until that point, the Committee had emphasised the importance of states adopting education and training measures (the obligation to fulfil/ promote human rights), as well as implementing policies to combat stereotypes and prejudices and to promote the dignity, capabilities and contributions of people with disabilities. ${ }^{98}$ Cusack notes that the inclusion of recommendations related to policy initiatives

demonstrates an awareness of the broad-ranging and holistic measures needed to challenge stereotyping and, in this, reflects lessons learned from the CEDAW Committee's evolving jurisprudence on stereotyping. ${ }^{99}$

The CRPD Committee has also paid particular attention to the need to challenge the stereotypical view of individuals with disabilities as being vulnerable or 'objects of charity' and, therefore, in 'need of protection'. 100

Since 2014, an ever-increasing number ${ }^{101}$ of concluding observations issued by the CRPD Committee urge states parties to 'promote positive perceptions' about people with disabilities through campaigns targeting the general population, the private sector and educational institutions. ${ }^{102}$ The Committee also recommends that states parties include organisations of persons with disabilities 'when developing and delivering nationwide campaigns, awareness-raising programmes or training on the human rights model of disability' ${ }^{103}$ Further-

95. Ibid., para. 10(b)(2). The Committee also seems to have (implicitly) rejected the ECtHR's finding in Alajos Kiss v. Hungary (Alajos Kiss v. Hungary, ECHR (2010), Application no. 38832/06) that disenfranchisement could be acceptable if an individualised assessment of voting capacity is carried out: CRPD Committee, Zsolt Buidosó and Others v. Hungary, above n. 91, para. 5.4.

96. See a similar analysis of States' concluding observations in Henrard, in this volume, in the context of Islamophobia.

97. Cusack, above n. 7 , at 20 .

98. Ibid., citing, among several others, CRPD Committee, Concluding Observations: Peru, UN Doc CRPD/C/ PER/CO/1 (2012), para. 19

99. Cusack, above n. 7, at 20.

100. Ibid. citing, among others, CRPD Committee, Concluding Observations: Austria, UN Doc. CRPD/C/AUT/CO/1 (2013), para. 22.

101. From the beginning of 2011 to the end of 2014, the term stereotype (search term 'stereo*') was mentioned 9 times in Concluding Observations. From the beginning of 2015 to the end of 2019, it was mentioned 58 times. From the beginning of 2011 to the end of 2014, the term prejudice (search term 'prejudice') was mentioned once in Concluding Observations. From the beginning of 2015 to the end of 2019, it was mentioned 8 times.

102. CRPD Committee, Concluding Observations: Turkey, UN Doc. CRPD/C/TUR/CO/1 (2019), para. 18(d).

103. CRPD Committee, Concluding Observations: Poland, UN Doc. CRPD/C/POL/CO/1 (2018), para. 14(b). 
more, the Committee suggests that states parties implement 'innovative' public awareness-raising and educational programmes ${ }^{104}$ for all relevant actors, including the media, judges and lawyers, the police, social workers and the general public, with the aim (inter alia) of addressing the language used in connection with people with disabilities, including women with disabilities. ${ }^{105}$

As outlined above, Article 8 CRPD acknowledges that the media plays a significant role in awareness raising. ${ }^{106}$ Bariffi asserts that the requirement in Article 8 CRPD 'includes not only the use of the media to broadcast specific disability-centred campaigns but also the way the whole media content portrays persons with disabilities' ${ }^{107}$ The media plays a fundamental role in challenging both direct and aversive disablism, by increasing representation of people with disabilities in all aspects of society. However, Bariffi contends that an analysis of state party reports shows

a clear trend, namely, that there are no general, nor mainstreamed, policies effectively implemented at domestic level, but rather isolated and disconnected initiatives or actions to raise social awareness as provided by article $8 .{ }^{108}$

In terms of the CRPD Committee's general comments, it has been asserted that the Committee missed 'key opportunities' to address issues of stereotyping in its early general comments. ${ }^{109}$ By its third general comment on women and girls with disabilities in 2016, however, the Committee deliberated quite extensively on compounded stereotyping. ${ }^{110}$ Later general comments urge states parties to put in place

specific rules relating to evidence and proof to ensure that stereotyped attitudes about the capacity of persons with disabilities do not result in victims of discrimination being inhibited in obtaining redress. ${ }^{111}$

This reflects, perhaps, the Committee's implicit acknowledgement of the limitations of educational measures alone and the requirement for states parties to adopt a wide range of measures aimed at changing hearts and minds.

104. CRPD Committee, Concluding Observations: Norway, UN Doc CRPD/C/NOR/CO/1 (2019), para. 14.

105. Ibid

106. On the role of the media, see also Art. 17 of the Convention on the Rights of the Child.

107. F. Bariffi, 'Analysis and Commentary of Article 8 on Awareness-Raising of the UN-CRPD', in M.A. Stein, I. Bantekas \& D. Anastasiou (eds.), The UN Convention on the Rights of Persons with Disabilities: A Commentary (2018), at 254.

108. Ibid., at 242 .

109. Cusack, above n. 7, citing CRPD Committee, above n. 68 , in which the terms 'stereotypes' and 'prejudice' are not mentioned.

110. CRPD Committee, General Comment 3, UN Doc. CRPD/C/GC/3 (2016), paras. 8, 17(e), 30, 38, 46 and 47.

111. CRPD Committee, Genernal Comment 6, above n. 48, para. 31(e).

\subsubsection{Evidence of Disability Mainstreaming in the UN Treaty Bodies?}

Degener claims that 'it would be contrary to the harmonization of international human rights law as well as to the mainstreaming ${ }^{112}$ of disability' in human rights law if the CRPD's model of inclusive equality were not applied broadly across the other UN bodies when dealing with disability claims. ${ }^{113}$

An advanced search conducted on the Universal Human Rights Index database revealed two decisions on disability stereotyping - one issued by the CEDAW Committee $^{114}$ and one by the CERD Committee ${ }^{115}$ - after the entry into force of the CRPD. It is noteworthy that neither of these decisions concerned prejudice and stereotyping between private parties, but the decision of R.P.B. v. Philippines ${ }^{116}$ nonetheless reveals important lessons regarding the extent to which the UN treaty bodies (should) ensure consistency in ruling on the rights of persons with disabilities in general, and specifically the right to non-discrimination.

R.P.B. related to a complaint brought before the CEDAW Committee by a Deaf girl who was raped by her neighbour. The applicant complained that the decision of the domestic court constituted discrimination under Article 1 CEDAW (the non-discrimination norm) and also under the CEDAW Committee's General Recommendations 18 and 19, related to women with disabilities and violence against women, respectively. ${ }^{117}$ The applicant alleged a failure of the state party to comply with its obligation to effectively protect women against discrimination in line with Article 2(c), (d) and (f) CEDAW. In that regard, it was claimed that the trial court 'relied on gender-based myths and stereotypes',118 failing 'to consider the rape in the context of her vulnerability as a [D] eaf girl'. ${ }^{119}$

The CEDAW Committee appeared to (implicitly) concur with the author of the communication, namely, that the domestic court had reasoned with 'manifest prejudice' against her as a Deaf minor victim. ${ }^{120}$ The Committee ruled that the judges viewed the author as an incredible witness and applied notions of how an 'ordinary Filipina female rape victim' should behave in the circumstances. ${ }^{121}$ Similarly to the obligations prescribed

112. See K. Skarstad and M.A. Stein, 'Mainstreaming Disability in the United Nations Treaty Bodies', 17(1) Journal of Human Rights 1 (2018).

113. T. Degener, General Comment No. 6 of the United Nations Committee on the Rights of Persons with Disabilities, 16 May 2018, Berkeley Comparative Disability Rights - webinar, cited in L. Waddington and A. Broderick, Combatting Disability and Realising Equality: A Comparison of the UN Convention on the Rights of Persons with Disabilities and EU Equality and Non-Discrimination Law (2018), at 45.

114. CEDAW Committee, R.P.B. v. Philippines, Communication No. 34/2011, UN Doc. CEDAW/C/57/D/34/2011 (2014)

115. Committee on the Elimination of Racial Discrimination, Pietri v. Switzerland, Communication No. 53/2013 UN Doc. CERD/C/91/D/53/2013 (2017).

116. CEDAW Committee, R.P.B. v. Philippines, above n. 114

117. Ibid., para. 3.1

118. Ibid.

119. Ibid.

120. Ibid., paras. 3.8 and 8.9

121. Ibid., para. 8.9 
by the CRPD Committee, the CEDAW Committee prescribed a review of legislation surrounding rape, ${ }^{122}$ as well as the provision of 'adequate and regular training' to the judiciary and legal professionals, so as to ensure that stereotypes and gender bias do not affect court proceedings and decision-making. ${ }^{123}$

Atrey remarks that R.P.B provides a useful example of how the CEDAW Committee's evaluative work 'can be channeled towards understanding and responding to [the] intersectional nature of gender violence with the perspective of intersectional integrity'. 124 However, despite the petitioner's invocation of the CRPD, the CEDAW Committee did not mention the CRPD in its decision. Notably, in finding that there was 'double discrimination' (rather than specifying whether it related to intersectional or multiple discrimination specifically), the CEDAW Committee referred to its own General Recommendation No. 18, which describes women with disabilities as a 'vulnerable group'. ${ }^{125}$ This is a term that the CRPD Committee (mostly) avoids ${ }^{126}$ and, as will be demonstrated in Section 4, the issue of language used by courts and treaty-monitoring bodies is an important one in seeking to avoid the perpetuation of stereotypes and prejudice.

\section{The ECtHR: Treading Lightly through Unchartered Waters?}

Since the entry into force of the CRPD, disability has featured increasingly as a human rights issue in Strasbourg. In the wake of Glor v. Switzerland, ${ }^{127}$ in which the Court stated that national authorities have a considerably reduced margin of appreciation with regard to disability discrimination, the ECtHR confirmed explicitly for the first time in Alajos Kiss v. Hungary ${ }^{128}$ the application of a standard of 'strict scrutiny' 129 in the context of disability.

Article 14 and Protocol 12 to the ECHR protect against discrimination, inter alia, on the basis of disability. It is well established that Article 14 ECHR cannot be invoked independently; rather, it is accessory to substantive ECHR rights. ${ }^{130}$ According to Arnardóttir, 'the key milestones in the development towards a more

122. Ibid., para. 9(b)(i)

123. Ibid. para. 9 (b)(iv).

124. S. Atrey, 'Lifting as We Climb: Recognizing Intersectional Gender Violence in Law', 5 Oñati Socio-legal Series 1512, at 1525 (2015).

125. CEDAW Committee, R.P.B. v. Philippines, above n. 114, para. 8.3.

126. The only mention of vulnerability by the CRPD Committee is in the cases of $X$ v. Tanzania, at para. 8.4 and in $Y$ v. Tanzania, at paras. 8.4 and 8.5. The notion of 'vulnerability' is used to describe the vulnerability of the authors of the communications as a result of the attacks and the failure to punish those, rather than describing people with disabilities themselves as vulnerable.

127. See, among others, Glor v. Switzerland, above n. 32

128. Alajos Kiss v. Hungary, ECHR (2010), Application no. 38832/06.

129. Ibid., para. 44.

130. Inze v. Austria, ECHR (1987), Application no. 8695/79, para. 36. robust substantive equality guarantee' are recognising indirect discrimination, the right to reasonable accommodation and positive obligations to protect and fulfil rights. ${ }^{131}$ Some of those aspects of protection from discrimination are evident in the ECtHR's case law. In the sphere of education, for instance, the Strasbourg Court has been increasingly willing to impose reasonable accommodation duties on contracting states to the ECHR, as will be demonstrated below. With regard to positive obligations to protect and fulfil disability rights across a range of ECHR provisions, the Strasbourg Court has wavered in its approach, as will be illustrated by analysing several post-CRPD cases that are relevant to disability discrimination, and particularly to prejudice and stereotypes in the interpersonal sphere.

\subsection{The Duty of Reasonable Accommodation and Ensuring Access to Inclusive Education}

Inclusive education is one way in which intergroup contact can be stimulated in the interpersonal sphere, and it provides a setting in which the (wrongful) assumptions underlying aversive disablism can be counteracted. Much has been written about stimulating affective ties between members of the dominant group and the minority 'outgroup'132 through creating intergroup contact, particularly in the sphere of race relations. ${ }^{133}$ However, it must be acknowledged that while increasing intergroup contact can serve to strengthen affective ties, it may not always have an impact on cognitive processes related to prejudice and stereotypes. ${ }^{134}$ Nonetheless, as Bariffi asserts:

[T] he right to inclusive education not only allows persons with disabilities to fulfil their right to education but it also allows other children without disabilities to raise awareness and understanding of disability as part of diversity in a natural inclusive environment. ${ }^{135}$

Certain cases of the Strasbourg Court acknowledge the benefits of inclusive education and deliberate on the obligations of contracting states to facilitate inclusion through providing reasonable accommodations.

In the 2016 decision of Çam v. Turkey, ${ }^{136}$ the Court found a violation of both Article 14 and Article 2 of Protocol No. 1 to the ECHR (on the right to education) following the refusal of the Turkish National Music Academy to enrol the applicant due to her visual impairment. The ECtHR focused on the importance of positive measures to ensure that students with disabilities enjoy education on a non-discriminatory basis and considered

131. O.M. Arnardóttir, 'Vulnerability under Article 14 of the European Convention on Human Rights Innovation or Business as Usual?', 4(4) Os/o Law Review 150 (2017)

132. See generally T.F. Pettigrew and L.R. Tropp, When Groups Meet: The Dynamics of Intergroup Contact (2011)

133. W.C. Byrd, Poison in the Ivy: Race Relations and the Reproduction of Inequality on Elite College Campuses (2017), at 12.

134. See generally Pettigrew and Tropp, above n. 132.

135. Bariffi, above n. 107, at 253.

136. Çam v. Turkey, ECHR (2016), Application no. 51500/08. 
that discrimination on the ground of disability extends to the refusal to provide a reasonable accommodation, in line with the CRPD. ${ }^{137}$ This was despite the fact that the applicant had not requested a reasonable accommodation from the domestic authorities. ${ }^{138}$ In essence, the ECtHR held that by refusing to enrol the applicant without accommodating her disability, the domestic authorities had prevented her, without any objective justification, from exercising her right to education. ${ }^{139}$

In a later case, Enver Şahin v. Turkey, ${ }^{140}$ the Strasbourg Court went even further than it had done in Çam to assess the suitability of the accommodation measures proposed to the applicant with a disability, ${ }^{141}$ who - following an accident - was unable to access the building of Firat University on account of the lack of adapted facilities. In finding a violation of both Article 14 and Article 2 of Protocol No. 1 to the ECHR, ${ }^{142}$ the Court noted that ensuring inclusive education forms part of the international responsibility of states. ${ }^{143}$ The ECtHR furthermore confirmed that Article 14 ECHR must be read in light of the CRPD's reasonable accommodation duty. ${ }^{144}$ In that regard, the Strasbourg Court held that the university in question had failed to look for alternative solutions that would have enabled the applicant to study under conditions as close as possible to those provided to students without disabilities, without imposing an undue or disproportionate burden on the entity concerned. ${ }^{145}$

While the Şahin judgment has been deemed to constitute 'a strong endorsement of the right to inclusive education' contained in the CRPD, ${ }^{146}$ in the more recent case of Stoian v. Romania ${ }^{147}$ the ECtHR demonstrated a more cautious approach in terms of enunciating the positive obligations of the state to facilitate access for individuals with disabilities to mainstream education, resorting instead to the state's margin of appreciation. In that connection, the ECtHR ruled that national authorities are 'better placed than an international court to evaluate local needs and conditions in this regard'. ${ }^{148}$

137. Ibid., para. 67. See J. Damamme, 'Disability Discrimination because of Denial of "Reasonable Accommodations": A Very Positive Connection between the ECHR and the UNCRPD in Çam v. Turkey', Strasbourg Observers, 01 April 2016, https://strasbourgobservers.com/category/ cases/cam-v-turkey/ (last visited 1 April 2020).

138. J. Damamme, 'Disability and University (Pragmatic) Activism: The Pros and Cons of Enver Şahin v. Turkey', Strasbourg Observers, 09 March 2018.

139. Çam v. Turkey, above n. 136, para. 69

140. Enver Sahin v. Turkey, ECHR (2018), Application no. 23065/12

141. A. Broderick, Case Note: Enver v. Sahin, Verbod op discriminatie op grond van handicap, Recht op onderwijs, VN-Gehandicaptenverdrag, 'Doeltreffende aanpassingen', European Human Rights Cases EHRC 2018/106, EHRM 30-01-2018.

142. See Enver Sahin v. Turkey, above n. 140, para. 75

143. Ibid., para. 62

144. Ibid., para. 67.

145. Ibid., para. 72.

146. O. Lewis, 'Strasbourg Case: Disabled Student Excluded from University Education', Doughty Street Chambers, 02 February 2018, https:// insights.doughtystreet.co.uk/post/102epfy/strasbourg-case-disabledstudent-excluded-from-university-education (last visited 1 April 2020).

147. Stoian v. Romania, ECHR (2019), Application no. 289/14.

148. Ibid., para. 109. See also Çam v. Turkey, above n. 136, para. 66.
Referring to the 'fair balance' test, ${ }^{149}$ the Court ruled that the domestic authorities had complied with their obligation to provide reasonable accommodation and had acted within the applicable margin of appreciation, ${ }^{150}$ despite indications by the domestic courts that the authorities had not taken adequate measures to facilitate the applicant's access to education.

A similarly reticent approach was demonstrated by the ECtHR in the 2019 case of Dupin v. France, ${ }^{151}$ where the Strasbourg Court took another step back from the more positive trends regarding inclusive education that were evidenced in Çam and Enver Şahin. Importantly, in Dupin, the CRPD' 152 was deemed 'notable by its absence' - at least there was no real engagement with the UN Convention. ${ }^{153}$

The more recent case law on education of the Strasbourg Court is therefore less encouraging in terms of facilitating intergroup contact in line with the CRPD's inclusive education provisions and provides less hope in terms of tackling the root causes of the aversive, and other forms of, disablism that pervade society. Indeed, as Deal points out, not endorsing inclusion can result in the fact that

well-meaning social policies that reduce the possibility of meaningful interactions between disabled people and others are therefore likely to be supported by aversive disablists, for instance: supporting segregated schooling due to the belief that it can offer a higher quality education to disabled children. ${ }^{154}$

\subsection{The Stance of the Strasbourg Court on Disability Hate Crime}

Another area in which the issue of disability prejudice and stereotypes has come before the Strasbourg Court is in relation to hate crime. At the end of 2012, the ECtHR decided for the first time, in Dordevic v. Croatia ${ }^{155}$ that the state's failure to protect against long-term, persistent harassment on the basis of disability and ethnic origin violated the ECHR.

Dordevic concerned two Croatian nationals of Serbian origin. The second applicant was the mother of, and full-time carer for, a man - Dalibor (the first applicant) - who was severely mentally and physically disabled. The applicants complained that they had been harassed, both physically and verbally, over a period of four years by children living in their neighbourhood, who committed 'a number of brutal acts' against the first applicant. ${ }^{156}$ The second applicant brought the matter to the

\footnotetext{
149. See Stoian v. Romania, above n. 147, para. 97.

150. Ibid., para. 110.

151. Dupin v. France, ECHR (2019), Application no. 2282/17.

152. For reference to the CRPD, see para. 12 of the judgment.

153. J. Lievens and M. Spinoy, 'Dupin v. France: The ECtHR Going Old School in Its Appraisal of Inclusive Education?', Strasbourg Observers, 11 February 2019, https://strasbourgobservers.com/2019/02/11/ dupin-v-france-the-ecthr-going-old-school-in-its-appraisal-of-inclusiveeducation/\#more-4304 (last visited 1 April 2020).

154. Deal, above n. 3, at 96.

155. ECtHR, Đordević v. Croatia, ECHR (2012), Application no. 41526/10.

156. Ibid., para. 24.
} 
attention of the police (among other authorities), who interviewed the children concerned, ${ }^{157}$ but concluded that they were too young to be held criminally responsible. ${ }^{158}$

The Strasbourg Court considered the first applicant's complaint under Article 3 ECHR (the prohibition of torture and inhuman and degrading treatment), recognising that positive obligations under that Article are not absolute and that they must 'be interpreted in a way which does not impose an impossible or disproportionate burden on the authorities'. ${ }^{159}$ The Court balanced the obligations inherent in Article 3 with the guarantees in other ECHR articles, which 'legitimately place restraints on the scope of [state] action to investigate crime and bring offenders to justice'. ${ }^{160}$ Balancing all considerations, the ECtHR denounced the Croatian authorities for having taken 'no relevant action of a general nature to combat the underlying problem' in spite of the fact that they knew that the first applicant had been 'systematically targeted and that future abuse was very likely to follow'. 161 The Court paid specific attention to the lack of policy decisions and monitoring mechanisms to prevent further harassment, and the lack of counselling put in place for the benefit of the first applicant, ${ }^{162}$ (seemingly) implying that these types of positive measures are required under the obligation to protect human (disability) rights.

In addition, the ECtHR held that the level of disruption caused to the second applicant's private life and 'acts of ongoing harassment' ${ }^{163}$ directed towards her son triggered the application of Article $8 \mathrm{ECHR}$ (the right to respect for private and family life), under which contracting states have a positive obligation to 'ensure respect for human dignity'. ${ }^{164}$ This is similar to what Liebenberg terms 'treatment as an equal' 165 and demonstrates a substantive model of equality in action within the ECtHR's jurisprudence.

Notably, even though the ECtHR had cited Article 5 CRPD (on non-discrimination) and Article 8 CRPD (on awareness raising) as relevant UN legal materials, ${ }^{166}$ the complaint under Article 14 ECHR was dismissed, since the applicants had not exhausted domestic remedies. It is unfortunate that the Strasbourg Court did not have the opportunity to consider the application of the nondiscrimination norm in Dordevic and to elaborate on positive measures in that context, particularly in light of the later judgment in Skorjanec v. Croatia, ${ }^{167}$ in which the Court found racist hate crime (leading to discrimi-

157. Ibid., paras. 14-15

158. Ibid., para. 20.

159. Ibid., para. 139.

160. Ibid

161. Ibid., para. 148

162. Ibid

163. Ibid., para. 153

164. Ibid., para. 152

165. S. Liebenberg, 'The Value of Human Dignity in Interpreting SocioEconomic Rights', 21 South African Journal on Human Rights 1, at 14 (2005).

166. Đordević v. Croatia, above n. 155, para. 79

167. Skorianec v. Croatia, ECHR (2017), Application no. 25536/14. nation by association) to be in breach of Article 14 ECHR.

It is noteworthy that, in Đordevic, the third-party intervener - the European Disability Forum - claimed that fear of difference is 'nourished' only when the potential victim is perceived as 'vulnerable'. ${ }^{168}$ Vulnerability (or perceived vulnerability) is often at the root of hate speech and hate crime, and it is acknowledged by some scholars ${ }^{169}$ that the construction of individuals with disabilities as vulnerable subjects has 'weakened the impetus' ${ }^{170}$ for the introduction of hate crime legislation and prevents courts and law enforcement authorities from identifying crimes as hate crimes per se. According to Roche, it also leads to the risk of facilitating the types of arguments advanced by the government in Dordevic, namely, 'that Dalibor had engaged in risky behaviour in light of his own vulnerability' ${ }^{171}$ by going outside on his own or that his mother had failed in caring for him by allowing him to go outside on his own. ${ }^{172}$

The vulnerable groups approach ${ }^{173}$ has rightly been viewed by some authors as a means of addressing structural inequalities. Peroni and Timmer argue that the ECtHR's use of the concept of 'group vulnerability'

represents a crucial step towards an enhanced antidiscrimination case law .... The Court's use of the term 'vulnerable groups'... does something: it addresses and redresses different aspects of inequality in a more substantive manner. ${ }^{174}$

While this contention has considerable merit, it must be acknowledged that the concept of 'vulnerability' does 'not sit particularly well with the disability rights agenda'. ${ }^{175}$ The Strasbourg Court has applied vulnerability analysis in several disability cases, beginning with Alajos Kiss, ${ }^{176}$ linking it to the 'considerable discrimination'177 that individuals with (certain types of) disabilities - psy-

168. Đordević v. Croatia, above n. 155, para. 133.

169. See A. Roulstone and H. Mason-Bish, 'Between Hate and Vulnerability: Unpacking the British Criminal Justice System's Construction of Disablist Hate Crime', 26(3) Disability and Society 351 (2012). See also the arguments made in Đordević v. Croatia, above n. 155, para. 131.

170. See Roulstone and Mason-Bish, above n. 169, at 351.

171. M. Roche, 'Failure to Stop Disability Harassment', 9 October 2012, www.localgovernmentlawyer.co.uk/adult-social-care/307-adult-carefeatures/11934-failure-to-stop-disability-harassment (last visited 1 April 2020).

172. See Roche, above n. 171. See also Đordević v. Croatia, above n. 155, para. 130.

173. See generally A. Timmer, 'Toward an Anti-Stereotyping Approach for the European Court of Human Rights', 11(4) Human Rights Law Review 707 (2011).

174. L. Peroni and A. Timmer, 'Vulnerable Groups: The Promise of an Emergent Concept in European Human Rights Convention Law', 11 International Journal of Constitutional Law 1056 (2013). Emphasis in original.

175. Broderick (2015), above n. 15, at 320 . See also the arguments by Maria Roche, who points out that,

"to assume 'vulnerability' is an inherent and unchanging characteristic of disabled people is to discriminate against them, is disempowering and sails close to a flawed conceptualisation of disability as weakness": Roche, above n. 171.

176. Alajos Kiss v. Hungary, above n. 128, para. 42.

177. Ibid. 
chosocial (mental) disabilities - have encountered in the past. The Court has even invoked the idea of group vulnerability in some cases to read positive obligations into ECHR rights, which is positive in itself. ${ }^{178}$ However, while the Court only made one reference to vulnerability in Dordević, ${ }^{179}$ it is arguable that employing the language of vulnerability can be a double-edged sword in the disability context: on the one hand, (potentially) increasing protection for the individual concerned, and, on the other hand, running the risk of leading to further stigmatisation regarding the perceived inabilities of people with disabilities. ${ }^{180}$ Moreover, the notion of 'group vulnerability' is at odds with the fact that the CRPD adopts an empowering approach, focusing on individual abilities and capabilities.

On the whole, Đordević has been deemed an 'important and welcome' judgment. ${ }^{181}$ It demonstrates that the ECtHR will step in when no concrete or integrated action to stop abusive behaviour is taken by domestic authorities, and it underlines the proactive role that state authorities should play to effectively counter hate crimes against people with disabilities. As mentioned above, however, harassment at the interpersonal level occurring in relations between private parties - will require coordinated action from a variety of domestic agencies, something which the Croatian authorities themselves did not manage to do in this context.

\subsection{Positive Duties in Strasbourg to Tackle} Employment-Based Discrimination?

The Strasbourg Court has also ruled on the severe effects of prejudice and stereotypes at work in $I B \mathrm{v}$. Greece, ${ }^{182}$ which concerned the dismissal from employment of a man who had contracted the HIV virus, following a letter penned by 33 of his fellow employees demanding his dismissal in order 'to preserve their health and their right to work'. ${ }^{183}$

Before the Strasbourg Court, the applicant claimed that he had been the subject of stigmatisation on the part of his colleagues, in that he 'had been treated like a pariah who should no longer be entitled to work'. ${ }^{184}$ He alleged a violation of his right to private life under Article 8 ECHR, on account of the Court of Cassation's ruling that his dismissal on the ground of his HIV status was lawful. The applicant also alleged discriminatory treatment contrary to Article 14 ECHR on account of the dismissal itself and the domestic Court's reasoning that it had been justified by the need to preserve a good working environment. ${ }^{185}$

178. See ZH v. Hungary, ECHR (2012), Application no. 28973/11, para. 31 See also para. 138 of Đordević v. Croatia, above n. 155, where the Court used similar language.

179. Đordević v. Croatia, above n. 155, para. 138.

180. Ibid, for the Government's submissions at para. 130, in contrast with the Court's approach at para. 138.

181. Roche, above n. 171.

182. IB v. Greece, ECHR (2013), Application no. 552/10.

183. Ibid., para. 10.

184. Ibid., para. 59.

185. Ibid., para. 48.
In finding a violation of both Articles 8 and 14 ECHR, the Strasbourg Court once again adopted the group vulnerability approach. It ruled that, by virtue of the fact that people living with HIV are a

vulnerable group with a history of prejudice and stigmatisation, States should only be afforded a narrow margin of appreciation in choosing measures that [single] out that group for differential treatment on the basis of their HIV status. ${ }^{186}$

The Court thereby extended its ruling in Kiyutin ${ }^{187}$ to a dispute between private parties in I.B.

The Court failed to mention the CRPD in I.B., although it had 'obvious relevance' to the decision. ${ }^{188}$ Nonetheless, it is evident, as argued elsewhere, ${ }^{189}$ that the CRPD's social model approach to disability infiltrated the Court's analysis of the material scope of Article 8 ECHR. The Strasbourg Court ruled that the treatment in question resulted in the applicant's stigmatisation and had 'serious repercussions' on his 'personality rights, the respect owed to him and, ultimately, his private life'. ${ }^{190}$ Furthermore, in deciding that there was no objective and reasonable justification for the treatment in question, the ECtHR adopted a CRPD-compliant approach (without drawing explicitly on the CRPD). ${ }^{191}$ This led the Court to narrow the margin of appreciation $^{192}$ and resulted in a finding of discrimination on account of the applicant's health status, which the Court held should be covered, either as a form of disability or in the same way as a disability, under the term 'other status' in Article 14 ECHR. ${ }^{193}$

Interestingly, the applicant claimed that 'the circumstances of his dismissal' did not render the principle of positive obligations inapplicable per se. ${ }^{194}$ The Greek government argued, however, that

neither Article 8, whether taken alone or in conjunction with Article 14, nor even Protocol No. 12 required member States to introduce legislation outlawing the dismissal of HIV-positive employees from a post in the private sector. ${ }^{195}$

The Strasbourg Court sidestepped the issue of positive obligations, noting that even if not all Council of Europe member states have enacted specific legislation in favour

186. Ibid., paras. 79 and 81 .

187. Kiyutin v. Russia, ECHR (2011), Application no. 2700/10, paras. 63-64. See also Novruk and Others v. Russia, ECHR (2016), Applications no. 31039/11, 48511/11, 76810/12, 14618/13 and 13817/14.

188. Broderick (2015), above n. 15, at 331.

189. See A.Timmer, 'HIV-based Employment Discrimination: The ECtHR Takes a Strong Stance in I.B. v. Greece', 21 October 2013, http:// strasbourgobservers.com/2013/10/21/hiv-based-employmentdiscrimination-the-ecthr-takes-a-strong-stance-in-i-b-v-greece/ (last visited 1 April 2020). See also Broderick (2015), above n. 15, at 331-332.

190. IB v. Greece, above n. 182, para. 72.

191. Ibid.

192. Ibid., para. 81

193. Ibid., para. 73

194. Ibid., para. 59.

195. Ibid., para. 56. 
of persons living with HIV, there is a 'clear general tendency towards protecting such persons from any discrimination in the workplace by means of more general statutory provisions'. 196

On the whole, Timmer is of the view that the I.B. judgment 'does not contain major innovations in the Court's Article 14 analysis', ${ }^{197}$ and she points to the fact that the legal reasoning does not provide much support for positive measures in the form of the duty to reasonably accommodate the applicant if his health status had actually diminished his ability to work. ${ }^{198}$

While the finding of disability-based discrimination, as a result of stigmatisation, is an important finding by the Strasbourg Court - in the sense that it seems to counteract (among others) a form of 'direct psycho-emotional' disablism ${ }^{199}$ that arises from various 'acts of invalidation'200 - the Court's apparent lack of support for positive measures is indeed noteworthy. Those measures have been deemed to constitute an essential component in targeting aversive disablism. That form of disablism may arise, according to Deal, in situations 'whereby an employer, through good intentions could decide not to put a disabled employee under additional pressure by exposing them to a new function or requiring them to attend a stressful training event', thereby placing the employee 'in a more vulnerable position with respect to his/her career'. ${ }^{201}$

\subsection{The Strasbourg Court and the Thorny Issue of Legal Capacity: Adjudicating According to 'Best Interests'?}

Another area in which the Strasbourg Court has been confronted with disability prejudice and stereotyping that can affect interpersonal relations is the field of legal capacity. Three particularly recent and relevant cases in that field are analysed below. ${ }^{202}$

A.-M.V. v. Finland ${ }^{203}$ concerned the complaint brought before the ECtHR by a man with an intellectual disability regarding the refusal of the domestic courts to replace his guardian, who had prevented him from deciding where, and with whom, he would live. The applicant alleged, in particular, a violation of Article 8 ECHR. The Strasbourg Court referred to Article 12 CRPD and the CRPD Committee's General Comment No. 1, both of which relate to legal capacity. Notably, the ECtHR remarked on the positive obligation of states parties to the CRPD to 'take action to develop laws and policies to replace regimes of substitute decision-making

196. Ibid., para. 83.

197. Timmer (2013), above n. 189.

198. Ibid.

199. See generally D. Reeve, 'Psycho-emotional Disablism and Internalised Oppression', in J. Swain, S. French, C. Barnes \& C. Thomas (eds.), Disabling Barriers - Enabling Environments (2014), at 92-98.

200. Ibid., at 93

201. Deal, above n. 3, at 100

202. See, in addition to the cases in this section, Shtukaturov v. Russia, ECHR (2008), Application no. 44009/05; DD v. Lithuania, ECHR (2012), Application no. 13469/06; Lashin v. Russia, ECHR (2013), Application no. 33117/02; Stanev v. Bulgaria, ECHR (2012), Application no. 36760/06.

203. A.-M.V. v. Finland, ECHR (2017), Application no. 53251/13. by supported decision-making, which respects the person's autonomy, will and preferences'. ${ }^{204}$ Notwithstanding this, the Strasbourg Court held that there had been no violation of Article $8 \mathrm{ECHR}$, since the applicant was unable to understand the implications of the matter in question. The Court implicitly applied a best interests standard, which is based on prejudice and stereotypes that people with disabilities are incapable, and is incompatible with Articles 12 and 23 CRPD. Moreover, Cojocariu is of the view that the Court extended the scope of the concept of 'protection of health' in Article 8(2) to

cover the woolly notion of "well-being", in order to accommodate interferences with the right to respect for private life in the "best interests" of the person concerned, beyond traditional concerns with harm to self or others. ${ }^{205}$

A similar approach by the ECtHR was evidenced in the later, 2018, case of Delecolle v. France. ${ }^{206}$ That case concerned a wealthy elderly man who had been placed under partial guardianship (curatelle renforcée) at the request of his adoptive daughter and who was refused permission to marry, since it was adjudged by the domestic authorities that he (apparently) could not understand the financial implications of this decision. In his complaint to the ECtHR, the applicant argued that his right to marry (contained in Article 12 ECHR) had been infringed. The Strasbourg Court invoked the permitted restrictions on that right - those of 'generally recognised public interest considerations' - to rule that the applicant was not 'deprived' of his right to marry, but was merely required to obtain his guardian's permission to do so. ${ }^{207}$ The Court afforded the state a wide margin of appreciation, reasoning that sufficient safeguards had been put in place and, ironically, that the impugned measure was intended to promote his autonomy. ${ }^{208}$ In that regard, Cojocariu argues that the Strasbourg Court did not engage with the facts of the case; rather, it focused on the procedural safeguards available to the applicant. ${ }^{209}$

Cojocariu rightly notes that the reasoning endorsed by the Strasbourg Court was impregnated with prejudice against and paternalism towards elderly people and people with disabilities'. ${ }^{210}$ What is particularly worrying is the fact that the applicant's adoptive daughter,

204. Ibid., paras. 42 et seq.

205. C. Cojocariu, 'A.-M.V. v Finland. Independent Living: A Bridge Too Far for the European Court of Human Rights', Strasbourg Observers, 10 May 2017, https://strasbourgobservers.com/2017/05/10/a-m-v-vfinland-independent-living-a-bridge-too-far-for-the-european-court-ofhuman-rights/ (last visited 1 April 2020).

206. Delecolle v. France, ECHR (2018), Application no. 37646/13

207. Ibid., paras. 54, 60 and 62 .

208. Ibid., para. 60.

209. C. Cojocariu, 'Loneliness that is Good for you: The European Court Addresses the Right to Marry of People with Disabilities', Strasbourg Observers, 3 December 2018, https://strasbourgobservers.com/ 2018/12/03/loneliness-that-is-good-for-you-the-european-courtaddresses-the-right-to-marry-of-people-with-disabilities/ (last visited 1 April 2020).

210. Ibid. 
who initiated the partial guardianship procedure, was apparently in the middle of a family conflict concerning financial interests in the applicant's property. ${ }^{211}$ Furthermore, the guardianship regime was put in place based on medical certificates that seemed to indicate 'slight cognitive disorder', 'psychological fragilities' and 'some degree of vulnerability', 212 giving rise to the question as to whether guardianship was a necessary measure at all in this instance. Indeed, a medical report sought during the domestic court proceedings stated that, although he had an intellectual disability and was unable to manage his property and finances, the applicant was capable of consenting to marriage. ${ }^{213}$ Viewed in that light, the Strasbourg Court's judgment displays overtly disablist reasoning. In her strong dissenting opinion, Judge Nußberger cogently argued that the right to marry was disproportionally restricted in this case. ${ }^{214}$

There is no doubt that the Strasbourg Court's standard of review in Delecolle perpetuates the types of prejudices and stereotypes that were evident at the national level. By granting the state a wide margin of appreciation and assuming that the domestic decisions were robust, without applying a substantive standard of review, the ECtHR did nothing to push states towards changing hearts and minds.

By way of contrast to the findings in the aforementioned cases, in the very recent case of Cința v. Romania, ${ }^{215}$ the ECtHR held that there had been a violation of Article 8 and Article 14 ECHR in the context of court-ordered restrictions on the applicant's contact with his daughter. The Court found, in particular, that the domestic authorities' decisions to restrict the applicant's contact had been based partly on the fact that he had a psychosocial disability ('mental illness'). While the ECtHR ruled that the fact that the applicant's mental health featured in the courts' assessment did not, in itself, raise an issue under Article $14 \mathrm{ECHR}$, relying on mental illness as the decisive element or even as one element among others may amount to discrimination when, in the specific circumstances of the case, the mental illness does not have a bearing on the individual's ability to take care of the child. ${ }^{216}$

Notably, the Court cited Article 12 CRPD (on legal capacity) and even the CRPD's human rights model of disability and its model of inclusive equality. ${ }^{217}$ On the whole, however, the Court's decision, while positive in its outcome, would not appear to be compatible with the pronouncements of the CRPD Committee. According to the Committee, 'mental illness' should not be a relevant consideration at all in restricting an applicant's rights.

211. Delecolle v. France, above n. 206, paras. 11-12

212. Ibid. Dissenting Opinion of Judge Nußberger, referring to para. 9 of the judgment.

213. Ibid. para. 9

214. Delecolle v. France, above n. 206, Dissenting Opinion of Judge Nußberger.

215. Cînța v. Romania, ECHR (2019), Application no. 3891/19.

216. Ibid., para. 68.

217. Ibid., paras. 31-32.
Furthermore, and in contrast to the CRPD Committee, the Strasbourg Court once again invoked the language of vulnerability to justify 'special consideration' for the rights of 'mentally-ill persons'. ${ }^{218} \mathrm{By}$ using the language of vulnerability and that of mental illness (rather than psychosocial disability, as the CRPD Committee ${ }^{219}$ does, representing the social construction of disability), there is potential for further entrenchment of disablist notions and behaviour in society. It is arguable that ensuring CRPD-compliant language in court decisions and, by extension, among the general public is something that only educational and training measures can target.

\section{Trends towards Convergence or Fragmentation in the Approaches of the UN Bodies and the Strasbourg Court}

Scrutiny of disability prejudice and stereotyping is in its 'embryonic stages'. ${ }^{220}$ Nonetheless, preliminary remarks concerning trends towards convergence or fragmentation in the approaches of the international and regional bodies analysed can be made.

As this article has demonstrated, the CRPD Committee has increased its references to the issues of prejudice and stereotyping in its concluding observations; and has proposed a mixed basket of legislative, funding and educational measures to tackle those issues. The Committee maintains a particular focus on awareness-raising and training measures, to be undertaken in conjunction with people with disabilities (through their representative organisations); and it also pushes states towards adopting legislative and individualised support measures. At times, however, the CRPD Committee has been criticised for its elaboration of 'somewhat aspirational'221 (positive) state obligations in seeking to ensure the fulfilment of certain rights, such as the right to legal capacity. ${ }^{222}$

It cannot be ascertained whether the CRPD's model of inclusive equality has travelled across the gamut of the international human rights treaty bodies. The data available is currently not robust enough to be able to detect definitive trends. Drawing on the one case of particular relevance in the context of this contribution -

\footnotetext{
218. Ibid., para. 77.

219. See CRPD Committee, above n. 68

220. Cusack, above n. 7, at 23.

221. Cojocariu (2018), above n. 209.

222. See also O. Lewis, 'Council of Europe', in L. Waddington and A. Lawson (eds.), The UN Convention on the Rights of Persons with Disabilities in Practice. A Comparative Analysis of the Role of Courts (2018) 89 , at 89.
} 
R.B.P. v. the Philippines - there appears to be a lack of coherence and an inconsistent use of concepts between the CRPD Committee and the CEDAW Committee when it comes to intersectionality and vulnerability analysis.

In relation to stereotyping, Cusack highlights that more work is needed

to ensure that, wherever possible, UN mechanisms seize opportunities to scrutinise disability stereotyping, and articulate the nature and scope of state obligations to address such stereotyping, including its compounded forms. ${ }^{223}$

He opines that the 'leadership of the CRPD Committee will be critical in this regard'.224

With regard to the CRPD and ECHR, 'growing synergies' have emerged in the Strasbourg Court's jurisprudence. $^{225}$ The ECtHR has affirmed that it views the CRPD as embracing 'a European and worldwide consensus on the need to protect people with disabilities from discriminatory treatment'. ${ }^{226}$ As Lewis asserts, this signals the Court's view that the CRPD is 'a globally important direction-setting treaty'. ${ }^{227}$ The ECtHR has increasingly drawn on the CRPD as an interpretive tool to ECHR rights, and it has outlined a duty of reasonable accommodation for contracting states in certain cases concerning access to education. However, as scholars point out, the Strasbourg Court has, to date, failed to fully engage with the CRPD, particularly in the field of legal capacity. ${ }^{228}$

By way of contrast with the UN treaty bodies, the Strasbourg Court has wavered in its approach to positive state duties to tackle prejudice and stereotypes. In certain judgments, such as Đordević, the Court lays emphasis on the importance of the obligation to protect, and pays specific attention to the lack of policy decisions and monitoring mechanisms to prevent further harassment. This strong stance may be on account of the serious nature of the acts in question and the extreme impunity evident in the case. In other judgments, such as I.B., the Court is less willing to step in to push states towards changing hearts and minds, and seems to agree with the domestic authorities that the ECHR does not require member states to introduce legislation outlawing the dismissal of HIV-positive employees in the private sector. The ECtHR has also retreated into the shadows in other cases that raised the thorny issue of legal capacity, such as A.-M.V. and Delecolle, according contracting states a wide margin of appreciation and resorting to limitation clauses on ECHR rights. This is not entirely surprising since, as Lewis confirms, the Strasbourg Court 'departs significantly from the CRPD Committee's insistence on legal capacity in all areas of life irre-

223. Cusack, above n. 7, at 23

224. Ibid.

225. Ferri and Broderick, above n. 33, at 264.

226. Glor v. Switzerland, above n. 32, para. 53.

227. Lewis (2018), above n. 222, at 108.

228. Ibid. Ferri and Broderick, above n. 33 spective of [the] nature or degree of disability or legal capacity status'. ${ }^{229}$ This presumably stems from the ECtHR's concern regarding the degree of legitimacy that it has vis-à-vis contracting states, a point which Henrard has elaborated on in connection with the Court's use of 'consensus analysis' as a means of justifying the appropriate level of scrutiny of restrictions. ${ }^{230}$

On the whole, Waddington affirms that the Strasbourg Court seems to run "hot and cold"231 in its case law on disability rights. In Delecolle, by way of contrast with $A .-M . V$., for instance, the Court did not mention the CRPD. According to Cojocariu,

with the Delecolle judgment, the Court reverts to an uncertain trajectory in the area of disability, characterised by a palpable inability to develop, and apply consistently, a coherent set of principles on difficult subjects such as legal capacity. ${ }^{232}$

Finally, a further area of fragmentation - not only between the UN bodies themselves, but also between the CRPD Committee and the ECtHR - relates to the use of language. As pointed out in this article, the ECtHR uses the language of vulnerability, in contrast to the CRPD Committee, which uses, instead, empowering language that emphasises capabilities. As argued above, the ECtHR's approach, while potentially increasing the protection afforded to individual applicants, arguably does not facilitate a change in hearts and minds towards viewing persons with disabilities as empowered individuals whose inherent capabilities should be the focus of analysis. Moreover, it would appear to run the risk of further entrenching aversive disablism.

\section{Conclusion}

Timmer maintains that stereotypes are both a 'cause and manifestation' of 'structural disadvantage and discrimination' against certain groups. ${ }^{233}$ This assertion rings particularly true in the context of people with disabilities, since deeply rooted systemic discrimination and stereotypical attitudes about their capabilities and contributions to society result in 'barriers to being' and 'barriers to doing'. ${ }^{234}$

229. Lewis (2018), above n. 222, at 128. Ferri and Broderick, above n. 33, at 187.

230. K. Henrard, 'How the ECtHR's use of European Consensus Modulates the Effective Protection of Fundamental Rights: Balancing Mandate, Legitimacy Concerns and Epistemological Uncertainty', in P. Kapotas and V. Tsevelekos (eds.), Building Consensus on European Consensus (2019), at 141-66.

231. L. Waddington, 'Handicap, Discrimination by Association, Indirect Onderscheid, Toegankelijkheid, VN-gehandicaptenverdrag', 130 European Human Rights Cases (2016), para. 18.

232. Cojocariu (2018), above n. 209.

233. Timmer (2011), above n. 173, at 708.

234. C. Thomas, 'How is Disability Understood? An Examination of Sociological Approaches', 16 Disability and Society 569 (2004). 
Mégret claims that state involvement in preventing negative encroachments occurring in the private sphere covers an 'important dimension of the experience of persons with disabilities'. ${ }^{235}$ The CRPD propelled the issue of disability discrimination, including in the interpersonal domain, into international human rights law. By endorsing the human rights model of disability and the inclusive model of equality, the CRPD requires states to 'delve deeper into the realm of equality law to grant disabled citizens a right of equal access to all areas of life'. ${ }^{236}$ Since attitudinal barriers are one of the most difficult barriers to eradicate, ${ }^{237}$ the CRPD imposes numerous positive obligations on states parties targeted at removing attitudinal barriers that are at the core of the marginalisation of people with disabilities.

This article has, to borrow the words of Perlin, analysed how far states should (and can) go to capture the hearts and minds of the public, in order to ensure that the rights of people with disabilities 'are incorporated freely and willingly - into the day-to-day fabric and psyche of society'. ${ }^{238}$ As noted in the introduction, this article primarily addresses jurisprudence which relates to prejudice and stereotypes that occur in relations between private parties, but it also discusses disablism, which - directly or indirectly - affects the exercise of the rights of people with disabilities in the interpersonal sphere.

As demonstrated throughout this article, the international human rights treaty bodies are like brave older siblings, stepping out into the unknown - without constraints - to pronounce a range of positive measures to be adopted by states parties, with a view to engaging in 'social engineering'. On the other hand, the Strasbourg Court imposes self-restraint and has recourse to the limits of its mandate whenever it is confronted with particularly contentious issues.

A mixture of positive duties, including legislative measures, have been considered appropriate by the UN treaty bodies to eliminate prejudice and stereotypes. However, as demonstrated above, discrimination that affects interpersonal relations - particularly discrimination that occurs between private parties - can be difficult to regulate. Furthermore, while effective safeguards can, and should, be adopted - ranging from a review of state policies and legal frameworks, to a review of the capacity available to monitor violations - wholesale reliance on the law is not desirable. This is because legislation, policies and institutional structures often mirror value-laden (disabling) social conventions and attitudes that emerge in a particular society. Moreover, while law can serve as an important tool in compelling individuals and groups to change their behaviour (and can sometimes lead to

235. F. Mégret, 'The Disabilities Convention: Towards a Holistic Concept of Rights', 12 The International Journal of Human Rights 261, at 266 (2008)

236. Broderick (2015), above n. 15, at 139.

237. Bariffi, above n. 107, at 230

238. M.L. Perlin, 'The ADA and Persons with Mental Disabilities: Can Sanist Attitudes Be Undone?', 8 Journal of Law and Health 15, at 22 (1993-1994) changes in hearts and minds over time), there is often a backlash against coercive measures.

Beyond legal measures, awareness raising and training (including in relation to language that potentially inflames prejudice and stereotypes) is required. These measures must target all relevant societal actors, particularly those involved in rights adjudication, including judges and prosecutors. It must be noted, however, that such measures have their limitations, as addressed throughout this article. In addition, as Bariffi acknowledges,

governmental commitment to conduct effective awareness raising policies to promote a positive image of persons with disabilities is scarce and generally guided by the prevalence of the medical model of disability. $^{239}$

To result in genuine changes to hearts and minds, Solstad Vedeler et al. are of the view that 'transformative strategies ${ }^{240}$ are more appropriate. The authors argue that awareness-raising activities are not sufficient; rather, drawing on Fraser's theories of social justice, they affirm that there 'continues to be a profound need to increase the redistribution of resources in order to facilitate an increase in educational achievement and employment participation'. ${ }^{241}$ Steadily increasing the level of participation and inclusion of people with disabilities in mainstream structures in society - education, employment, political and cultural life, among others - facilitates intergroup contact. Thus, societal structures need to be changed. In turn, affective ties can be built and strengthened. This should, at the very least, result in changing hearts, although the cognitive dimension of prejudice may take longer to tackle.

Ultimately, states cannot be 'forced' to change hearts and minds, but a desire to effect change can seep into the collective conscience (and into political will), in particular through the efforts of civil society. Essentially, more inclusion and participation of people with disabilities themselves and their representative orgranisations is needed in policy processes. ${ }^{242}$ Their inclusion at all levels is necessary, among other reasons, to challenge the depictions of disability that are contained in popular culture, certain religions and in historical and medical accounts of disability. As Bariffi points out, 'the system of values, beliefs, traditions, and the social image about disability which is built at individual, community, and media levels sets the groundwork for any possible social change'. 243

In its 2018 general comment on equality, the CRPD Committee affirmed that the efforts by states parties 'to overcome attitudinal barriers to disability have been

239. Bariffi, above n. 107, at 244.

240. J. Solstad Vedeler, T. Olsen \& J. Eriksen, 'Hate Speech Harms: A Social Justice Discussion of Disabled Norwegians' Experiences', 34(3) Disability and Society 368, at 380 (2019).

241. Ibid.

242. CRPD Committee, General Comment 7 on Participation, UN Doc. CRPD/C/GC/7 (2018).

243. Bariffi, above n. 107, at 230 
insufficient', and that 'enduring and humiliating stereotypes, and stigma of and prejudices against persons with disabilities as being a burden on society' remain. ${ }^{244}$ Courts and quasi-adjudicatory bodies can play a role in pushing states towards facilitating change in this regard. The international and regional treaty bodies and courts need to develop a coherent body of jurisprudence that can be translated into concrete action at the domestic level. Ultimately, however, it is only by increasing the participation and inclusion of people with disabilities in every aspect of society that states can target the root causes of prejudice, stereotypes and 'othering' that persist. This is wholly in line with the CRPD's model of inclusive equality. 